\title{
Geometric Model of a Coastal Aquifer to Promote the Sustainable Use of Water. Manglaralto, Ecuador
}

\author{
Paul Carrión-Mero ${ }^{1,2, *(\mathbb{D})}$, Ximena Quiñonez-Barzola ${ }^{3}{ }^{\text {, Fernando Morante-Carballo }}{ }^{2,4,5, * \mathbb{D} \text {, }}$ \\ F. Javier Montalván ${ }^{6}\left(\mathbb{D}\right.$, Gricelda Herrera-Franco ${ }^{5,6}{ }^{(D)}$ and José Plaza-Úbeda ${ }^{7}$ (D)
}

1 Facultad de Ingeniería en Ciencias de la Tierra, ESPOL Polytechnic University, Guayaquil P.O. Box 09-01-5863, Ecuador

2 Centro de Investigaciones y Proyectos Aplicados a las Ciencias de la Tierra (CIPAT), ESPOL Polytechnic University, Guayaquil P.O. Box 09-01-5863, Ecuador

3 Junta Administradora de Agua Potable Regional de Manglaralto (JAAPMAN), Manglaralto 241754, Ecuador; xiyoquin@espol.edu.ec

4 Facultad de Ciencias Naturales y Matemáticas (FCNM), ESPOL Polytechnic University, Campus Gustavo Galindo Km. 30.5 Vía Perimetral, Guayaquil P.O. Box 09-01-5863, Ecuador

5 Geo-Recursos y Aplicaciones GIGA, ESPOL Polytechnic University, Campus Gustavo Galindo Km. 30.5 Vía Perimetral, Guayaquil P.O. Box 09-01-5863, Ecuador; grisherrera@upse.edu.ec

6 Facultad de Ciencias de la Ingeniería, Universidad Estatal Península de Santa Elena (UPSE), La Libertad 240204, Ecuador; fmontalvan@upse.edu.ec

check for updates

Citation: Carrión-Mero, P.;

Quiñonez-Barzola, X.;

Morante-Carballo, F.; Montalván, F.J.; Herrera-Franco, G.; Plaza-Úbeda, J.

Geometric Model of a Coastal Aquifer to Promote the Sustainable Use of Water. Manglaralto, Ecuador. Water 2021, 13, 923. https://doi.org/ 10.3390/w13070923

Academic Editors:

José Álvarez-García,

Amador Durán-Sánchez and María de la Cruz del Río-Rama

Received: 30 December 2020

Accepted: 20 March 2021

Published: 28 March 2021

Publisher's Note: MDPI stays neutral with regard to jurisdictional claims in published maps and institutional affiliations.

Copyright: (c) 2021 by the authors. Licensee MDPI, Basel, Switzerland. This article is an open access article distributed under the terms and conditions of the Creative Commons Attribution (CC BY) license (https:/ / creativecommons.org/licenses/by/ $4.0 /)$.
7 Economics and Business Department, University of Almería, Ctra. Sacramento s/n, La Cañada de San Urbano, 04120 Almería, Spain; japlaza@ual.es

* Correspondence: pcarrion@espol.edu.ec (P.C.-M.); fmorante@espol.edu.ec (F.M.-C.); Tel.: +593-998265290 (P.C.-M.); +593-96-385-5119 (F.M.-C.)

Abstract: Modeling an aquifer provides significant advantages when evaluating and estimating the water resource for its sustainable use. This study focuses on the rural parish Manglaralto, a semi-arid area with a shortage of water, and without supply service by the public network. Still, it has a great demand for supply by the local and floating population (tourism). This has caused the coastal aquifer, which supplies the area's water, to show signs of overexploitation, and its natural balance is compromised. The aim is to establish a geometric model of the aquifer through geological and geophysical analysis to set sustainable water-use guidelines. The methodology includes: (i) the processing of the current technical and hydrogeological information to know the aquifer's data; (ii) geometric modeling of the aquifer through the correlation of technical information, using the GeoModeller software; (iii) proposals for the sustainable use of water in the framework of the United Nations' Agenda 2030. The geometric model results reveal that the aquifer's thickness varies from $4 \mathrm{~m}$ at the head of the river to $30 \mathrm{~m}$ at the sea's mouth. The volume of water is estimated at $13.6 \mathrm{Hm}^{3}$. The sustainable-use proposals ensure that more than half of the population receives the community company's service. More than $40 \%$ of the territory is a protected area, and $64 \%$ of the population has sewerage service. This geometric model is a visual contribution that allows us to know the aquifer's shape and establishes guidelines that help strengthen the water supply's development and sustainability over time.

Keywords: coastal aquifer; geometric model; sustainable management; GeoModeller

\section{Introduction}

As natural resources become scarce and ecosystems appear to be degrading despite all improvement measures, the constant extraction of resources is subject to broad public debate, fueled by increasing demand for resources, restrictions on their use, and climate change [1-3]. Sustainable development faces one of its most significant challenges, the increasing scarcity of water, which will grow with the increase in the world population estimated for 2030, to affect 8600 million inhabitants [4]. Added to this, the rate of climate 
change is intensifying [5]. Currently, a large proportion of the world's population is experiencing water stress [6]. Studies warn of the likelihood of a drinking water shortage soon. This shortage will affect all sectors and agents, mainly water supply to cities [7,8]. According to reference data from the World Health Organization, a person requires $50 \mathrm{~L} /$ day to cover their basic needs and reduce public health risks [9]. The global water demand is expected to grow above the current use, between $20 \%$ and $30 \%$, until 2050 [10].

The availability of water resources is a challenge for many communities since it is a scarce resource, limiting social and economic development [11,12]. In arid and semi-arid areas, the primary sources of water are aquifers. Furthermore, coastal areas concentrate more than half of the global population [13]. Due to increasing urbanization in coastal areas, which leads to an increase in water demand, and variations in climatic conditions (extreme flooding or drought), there has been a decrease in groundwater levels, as well as its quality deterioration (due to saline intrusion) [14-18].

There is a relationship between water access and poverty, which translates into development and sustainability [19]; since groundwater exploitation is correctly programmed, it influences socio-economic development [20]. The water reserves of an aquifer are estimated for strategic planning towards development. One method used to improve groundwater reserves in aquifers is the infiltration of surface water. Therefore, artificial recharge is used to increase piezometric levels (volume increase) and enhance groundwater quality. The artificial recharge technique through surface water infiltration has been used throughout the world for more than 200 years [21]. An example of sustainable use is in Rajasthan (India) with the MARVI project (management of aquifer recharge and sustained groundwater use through interventions at the village level). They have created check dams in streams to increase recharge artificially [22]; they also plan their plantations by measuring groundwater levels [23].

Effective aquifer management is becoming an essential aspect of water resource management strategies [24]. At the global level, the United Nations' Agenda 2030 considers the sustainable development goals (SDGs) to achieve sustainability in any project $[25,26]$. For these fines, three-dimensional (3D) modeling methods are increasingly being used, digital representations of the object of study's characteristics in three dimensions. Software tools for 3D modeling require updates for intricate, detailed, and high-quality models [27]. One of these types of software is GeoModeller [28,29], which allows the modeling of complete formations respecting the geological characteristics by using a series of geological, hydrogeological, and geophysical data $[27,30]$.

Geometric 3D models are essential for visualizing an aquifer's geometric relationships and understanding the influence between subsoil layers; they are based on advanced studies such as fault relationships [31] and flow models [32]. They also allow evaluation of the water resource and favorable areas for settlement or recharge [33]. They are also useful in proposing sustainable development and management policies, as is the case of the Küçük Menderes river basin, in western Turkey [34], where the units and the aquifer's geometry have been defined with a model flow. In Spain, they obtained the 3D model of the Loma de Úbeda aquifer by processing geological and geophysical data in software to model the aquifer flow [35]; a similar study was conducted in Musi, India [36]. A 3D model was set up in Australia to improve the geometric visualization and subsequent volumetric calculation of the Barwon Downs Graben aquifer [37]. In Ecuador, aquifer studies to determine management criteria occur in the Cutuchi river aquifer in the northern Andes. The aquifer was mathematically modeled to propose preventive strategies and mitigation of environmental impact [38,39].

The challenge occurs in the coastal areas of Ecuador, north of the Santa Elena province (Manglaralto river basin), where various types of studies have been carried out, such as proposals for the construction of wells for water extraction, management models, enhancements of the river-aquifer system, hydrogeological analysis of the basin, and a hydrochemical analysis of groundwater [40-42]. A next stage contemplates the geometric 
study, which is essential to visualize and understand the aquifer, recognize water catchment sites, sustainable use, and decision-making in managing the resource.

The water supply's biggest problems occur, especially in January to March, due to the beach season. The increase in the floating population (tourists) triggers high consumption values, especially in the Montañita, Manglaralto, and Libertador Bolívar communities [43]. The season coincides with the wet season, where there is the most significant amount of precipitation, which is the only source of recharge of the aquifer [44]. However, according to the National Institute of Meteorology and Hydrology, the maximum monthly mean precipitation of the Manglaralto watershed is $100 \mathrm{~mm}$, with water deficits during all years [42]. These imply a low natural recharge of the aquifer.

\section{The Study Case}

Ecuador presents a high climatic variability with very rainy and other semi-arid zones, the latter being Santa Elena's province. The province comprises three municipalities (Santa Elena, La Libertad, and Salinas), of which $44.8 \%$ of the population is rural [44,45] and $42.46 \%$ is below the income poverty line $[45,46]$. The coastal area, north of Santa Elena, has been promoted for tourism for approximately ten years by the "Ruta del Spondylus" to improve its economic resource. This route travels along the Ecuadorian coastline, connecting coastal towns with many tourist booms [47], as is the case with the Manglaralto.

Manglaralto has 18 communes, of which six (Manglaralto, Montañita, Río Chico, Libertador Bolívar, Cadeate, and San Antonio) are supplied with water extracted from the aquifer associated with the Manglaralto River, through 12 wells administered by the Manglaralto Drinking Water Board (JAAPMAN) (Figure 1).

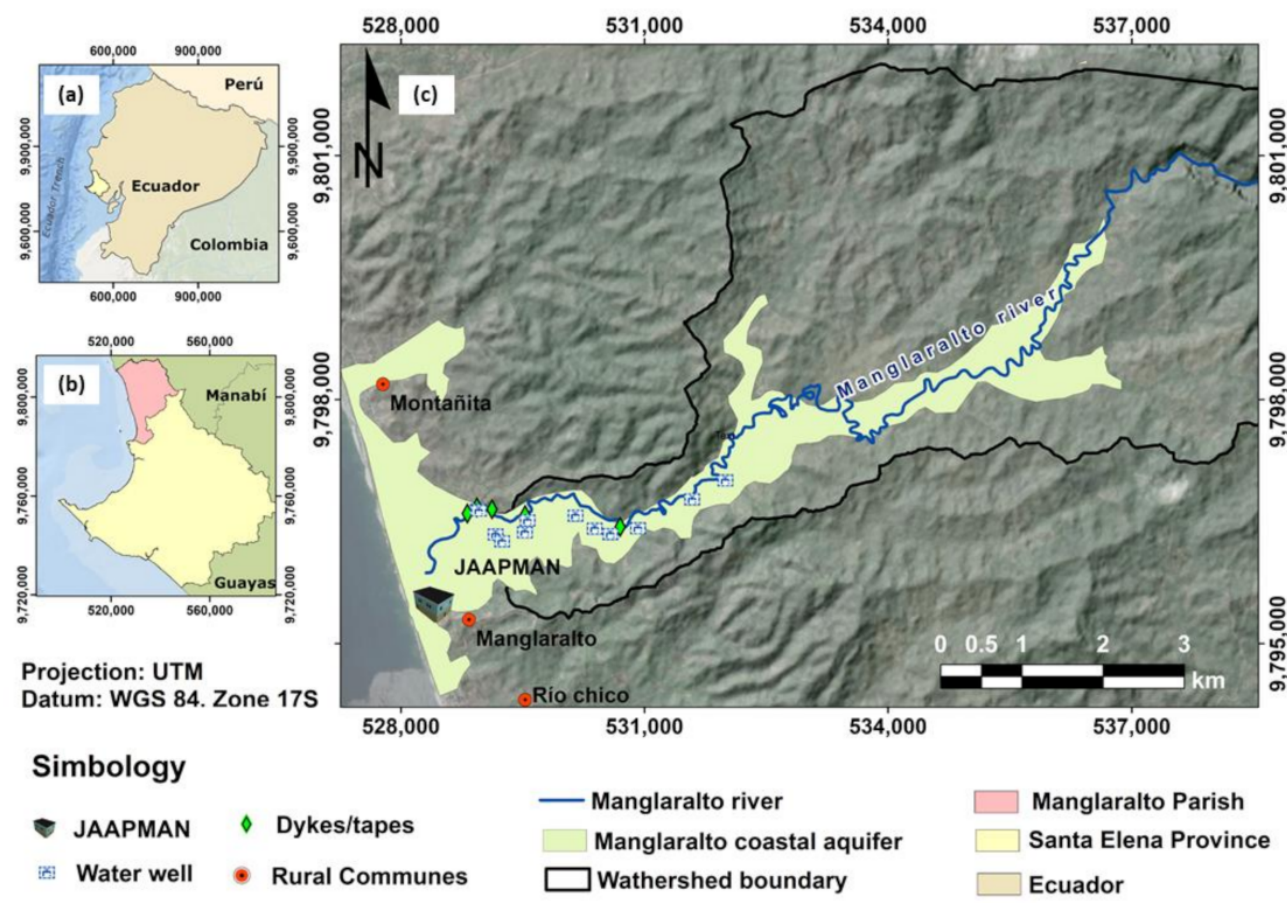

Figure 1. (a) Study area location in Ecuador. (b) Parishes of the province of Santa Elena and location of the parish of interest. (c) Zone of the aquifer associated with the Manglaralto River, including the design of 'tapes' (word of traditional/ancestral knowledge) or artisanal dykes.

A name used in the commune proposes to accumulate rocks and sediments in certain parts of the riverbed to try to dam the water and allow it to collect, preventing the water from escaping into the ocean. It facilitates the artificial recharge of aquifers and to establish possibilities for resilience [48,49]. Additionally, these engineering works, carried 
out traditionally, rescuing ancestral knowledge, generate opportunities for research and applications of geotourism based on the sector's geo-biodiversity [50-54].

Under these premises, in the case of Manglaralto, is it possible with technical, topographic, geological, and geophysical information to estimate the geometric model of the aquifer and plan its sustainable use? This study aims to establish a geometric model of the Manglaralto aquifer through geological-geophysical analysis to set sustainable water use guidelines. The aquifer's resilience capacity, in terms of planning its sustainable management, can be realized through computer tools, the rescue of ancestral knowledge, solutions based on nature, and the mitigation of environmental impacts [55-57].

\section{Materials and Methods}

The study was implemented using a three-phase methodology, as shown in Figure 2. In phase I, the previous information on topography, geology, geophysics, and hydrogeology was processed to plan geophysical campaigns. All this information was analyzed to visualize a conceptual model. In phase II, geological and geophysical information was correlated with the aquifer's geometry model to estimate its volume. In phase III, through the model and volume estimation, proposals for the sustainable use of the water resource were designed.

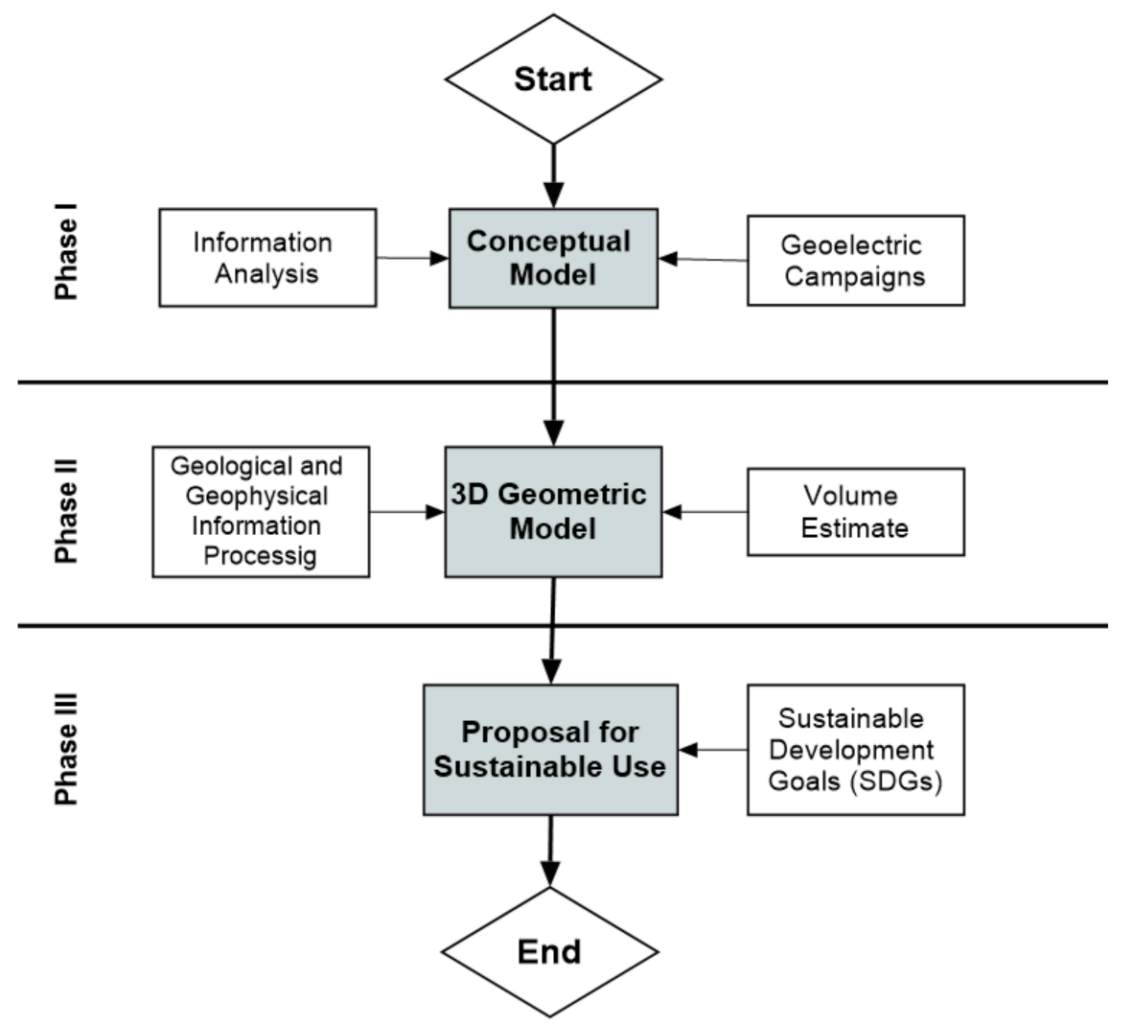

Figure 2. Scheme of the methodology of this study.

\subsection{First Phase}

The 3D geometric model was necessary to review the topographic, geological, geophysical, and hydrogeological information to identify the area and plan the geoelectric campaigns $[41,42,58]$. Forty-three Vertical Electrical Soundings (VES), whose locations are shown in Figure 3, were carried out on the riverside of the Manglaralto river, using the Schlumberger technique with the Terrameter SAS 1000 equipment, with maximum external openings $(\mathrm{AB} / 2)$ of $215 \mathrm{~m}$, and maximum internal openings $(\mathrm{MN} / 2)$ of $20 \mathrm{~m}$. With this set of information, the data was analyzed and correlated. It was also contrasted with a conceptual model to have a preliminary idea of the model according to the area's reality. 


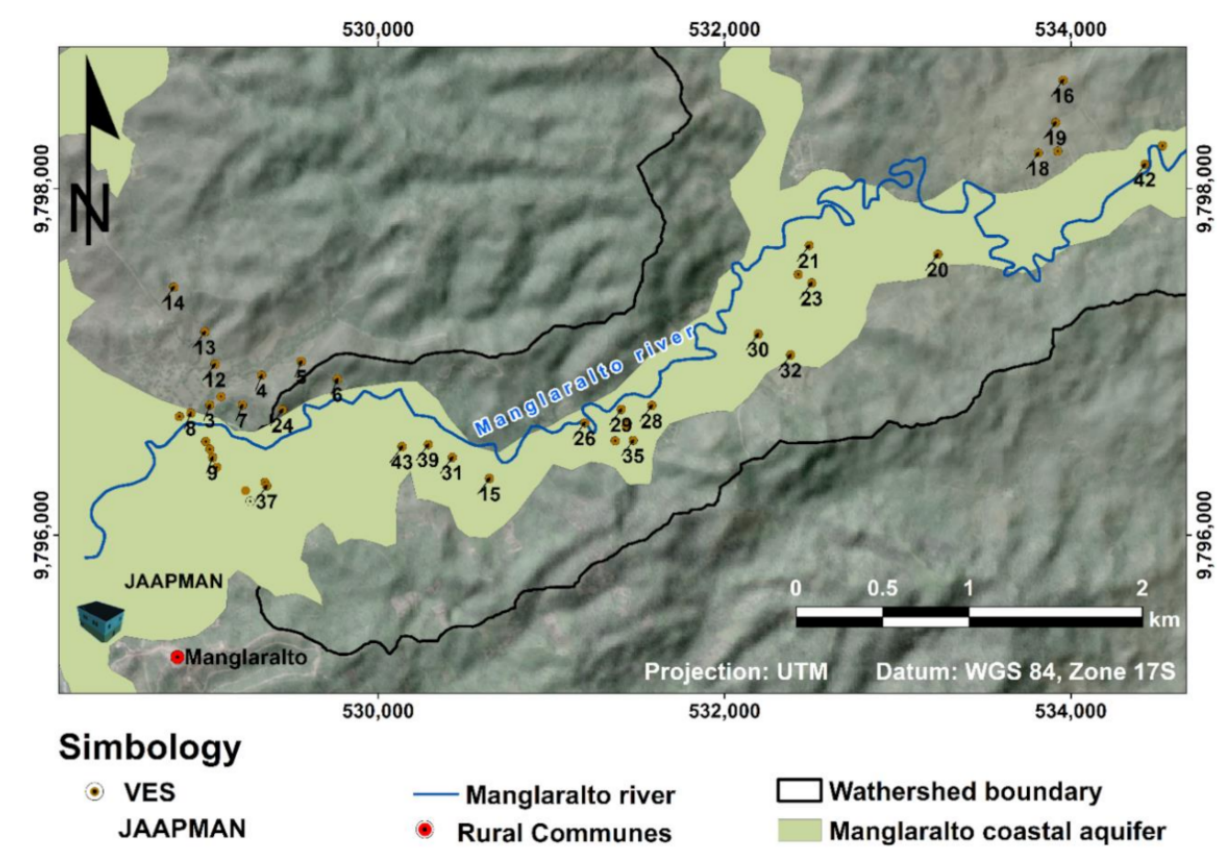

Figure 3. Locations of Vertical Electrical Soundings (VES) in the Manglaralto basin.

\subsection{Second Phase}

The 3D geometric model made in this study was created with GeoModeller software, which is software used for three-dimensional modeling [28,29]. The methodology is related to the applications of studies carried out in other aquifers [59-63], in which geological and geophysical information has been used to create three-dimensional models of the subsoil in the program.

The information obtained, such as the geological map or geoelectric data, must be processed before being included in the 3D GeoModeller v4.0.7 software. The input data follow the process described in Figure 4. The interpretation of the VES was carried out in the IPI2win software, and later the results were transferred to the Microsoft Office Excel 2019 program. The electrical sounding information is divided into three Excel files (with a .csv extension): the collar file contains the $x, y, z$ coordinates of the sounding points; the survey file contains sounding depth, azimuth, and inclination data; and the geology file locates the depths at which the layers are found, relating them to the corresponding formation/lithology. The digitization of the geological contacts, of the units to be modeled, was carried out in ArcGIS 10.5. (with extension .shp). In this case, three hydrogeological units (permeable, semi-permeable, and impermeable) were modeled.

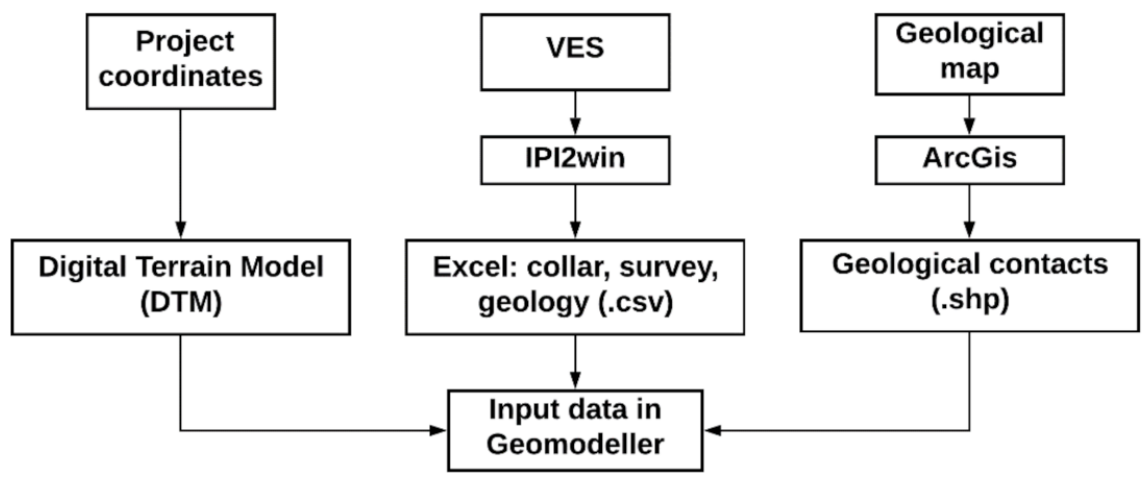

Figure 4. Input data schema in the GeoModeller software. 
The creation process of the model is shown in Figure 5. The study area coordinates first entered are shown in Table 1. It was necessary to create a topographic surface to adjust the model to the topography. A digital terrain model (DTM, with .tif extension) was necessary, with which a 3D surface of the area was obtained. Next, the geoelectric models resulting from the vertical electrical soundings (VES, with extension .csv) are introduced, with their contacts and orientations. The program correlates the input data, thus obtaining a proto-three-dimensional model of the aquifer. This model was then verified with the information from the existing wells in the area, to adjust to reality.

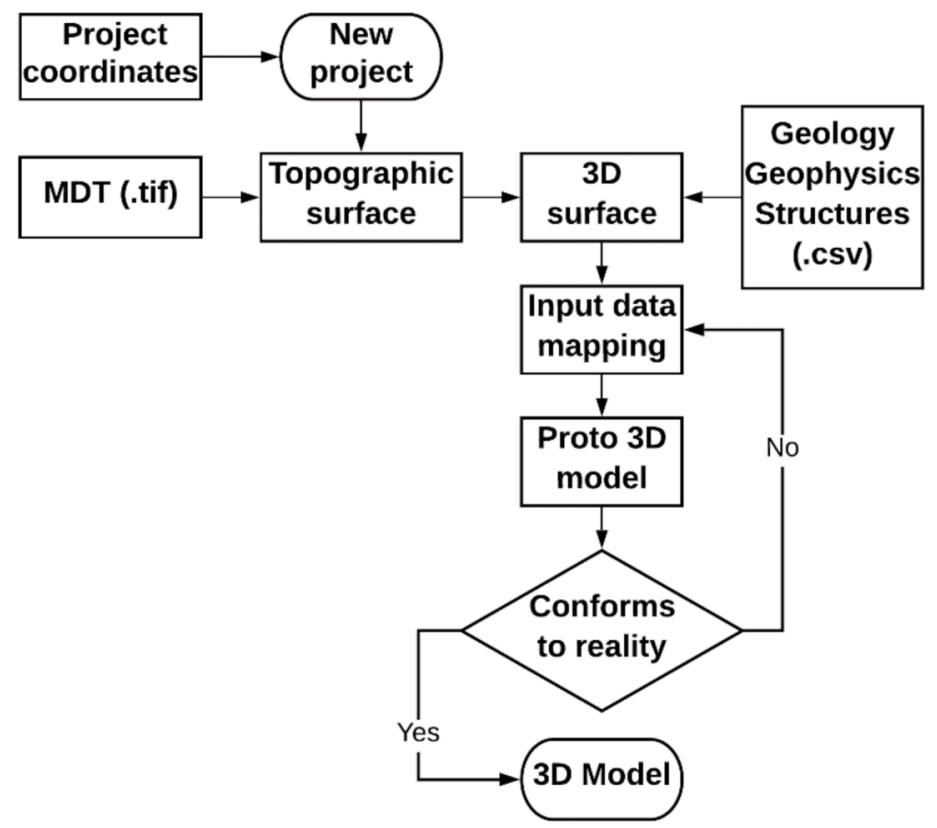

Figure 5. GeoModeller software process creation model.

Table 1. Coordinates of the study area. ${ }^{*}$ UTM: Universal Transverse Mercator/WGS 84: World Geodetic System 1984.

\begin{tabular}{ccc}
\hline Limits (UTM/ WGS $84^{*}$ Zone 17S) & Minimum (m) & Maximum (m) \\
\hline Coordinates X & 528,000 & 537,000 \\
Coordinates Y & $9,795,000$ & $9,800,000$ \\
\hline
\end{tabular}

Once the model better represents the area's physical environment, an estimate of the aquifer's volume was made. To do this, by creating regular orthogonal grids in the program, a gross volume of the discretized units was calculated. In this case, they are hydrogeological units differentiated by their capacity to store water- the gross volume of the permeable unit multiplied by the stratum's porosity. The result was compared with the piezometric levels measured in the wells to estimate water volume in the aquifer.

\subsection{Third Phase}

Sustainable-use proposals are presented in a matrix. According to the Brundtland Commission's criteria [64], the four Environmental, Cultural, Social, and Economic factors (ECSE) should be analyzed. Each factor is related to the SDG indicators [65]. Also, the status of the indicators is detailed. The factor-indicator relationship allows us to offer proposals to strengthen the water supply's development and sustainability. It is presented in a Venn diagram that allows visualization of the critical points for the aquifer's sustainable management. 


\section{Results}

\subsection{Information Synthesis}

The area's topography was obtained from the digital elevation model: ASTER Global Terrain Model (ASTGTM) with a resolution of $12.5 \mathrm{~m}$; and the geological map of Ecuador. Scale 1: 100,000: Manglaralto Leaf (3488 MIV-E), in Figure S1 (Supplementary Material). The coastal aquifer's characteristics within a basin of order four can be highlighted from the hydrogeological information, with a slope towards the Pacific Ocean, as shown in Table 2.

Table 2. Aquifer data. This information is based on various investigations [40-42].

\begin{tabular}{|c|c|}
\hline \multicolumn{2}{|c|}{ Manglaralto River Coastal Aquifer Data } \\
\hline Static level (depth from the surface) & 1.2 to $9.7 \mathrm{~m}$ \\
\hline The average porosity of the gravel/sand layer & $22 \%$ \\
\hline Darcy's permeability ("real") & $1.59-5.15 \mathrm{~m} /$ day \\
\hline Well-extraction flow & Rainy season: $12 \mathrm{~L} / \mathrm{s}$; dry season: $5 \mathrm{~L} / \mathrm{s}$ \\
\hline
\end{tabular}

The geoelectric campaigns comprised 43 VES, 40 that were obtained from geophysical field surveys, and another three that were taken from other campaigns [42]. They have been interpreted with the IPI2win software, and resistivity curves were adjusted to represent the strata with an error of less than $6 \%$. In Figure 6 and Table 3, the program's interpretation of VES $N^{\circ} 15$ is shown, obtaining the number of subsoil layers, the depth, and each one's thickness. The analysis of the information, and the geological and geophysical study, reinforce the study basin's hydrogeological system's conceptual model, shown in Figure 7.

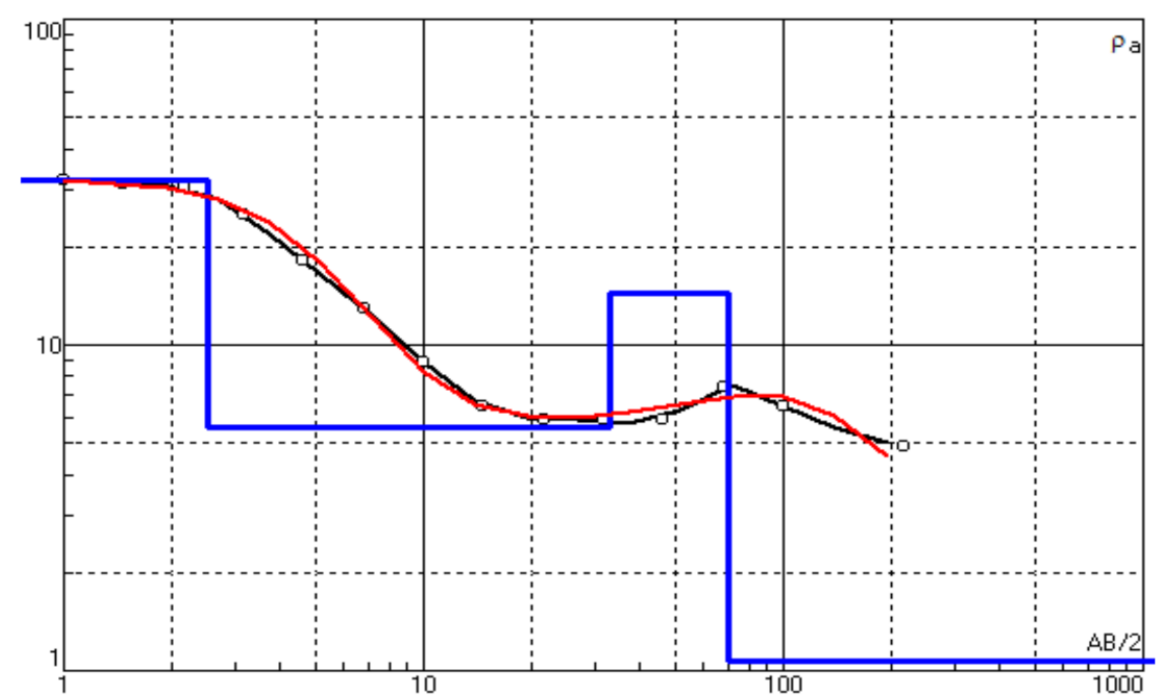

Figure 6. Value adjustment curve of VES $\mathrm{N}^{\circ} 15$.

Table 3. Results for VES $N^{\circ} 15$ analyzed with IPI2win.

\begin{tabular}{ccc}
\hline Resistivity $(\boldsymbol{\Omega} \cdot \mathbf{m})$ & Thickness $(\mathbf{m})$ & Depth $(\mathbf{m})$ \\
\hline 32.2 & 2.5 & 2.5 \\
5.59 & 30.3 & 32.8 \\
14.4 & 37.5 & 70.3 \\
1.07 & & \\
\hline
\end{tabular}




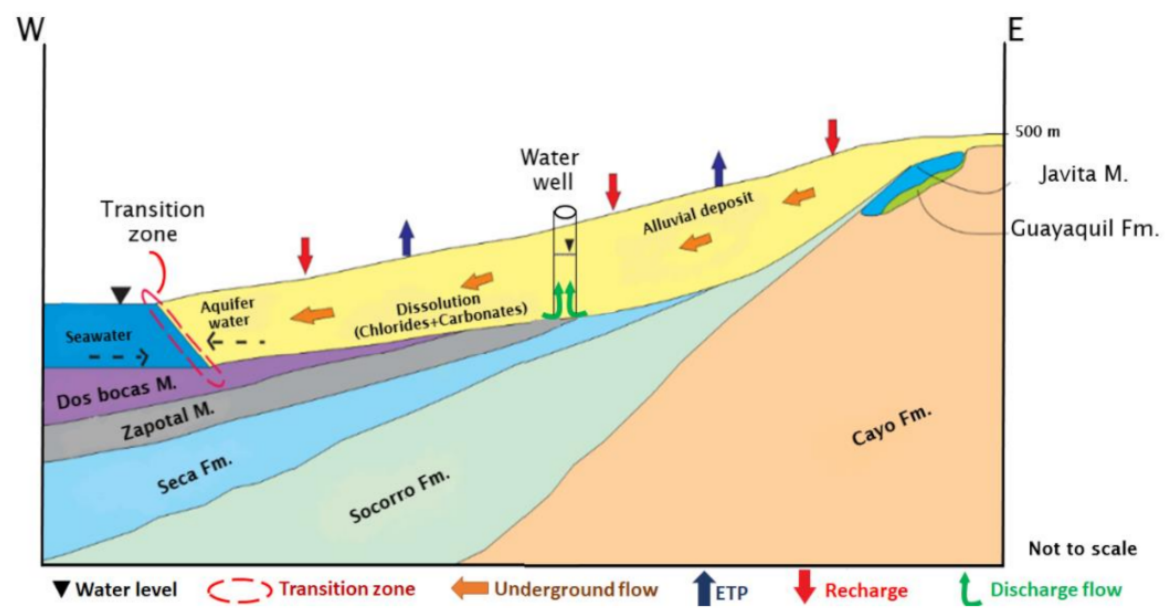

Figure 7. Alluvial conceptual model. Modified from the study [44].

The intrusion of seawater is present in the coastal aquifer. The chemical analyses carried out indicate that wells P2, P3, and P4, which are the closest to the sea, reach chloride concentrations of $34.48 \mathrm{mmol} / \mathrm{L}, 10.42 \mathrm{mmol} / \mathrm{L}$, and $20.37 \mathrm{mmol} / \mathrm{L}$, respectively. In interior wells below $3.04 \mathrm{mmol} / \mathrm{L}$ was found. This concentration indicates that the freshwater-seawater transition zone is located in this area [44].

Three hydrogeological units were modeled in the basin, shown in Figure 8: (i) unit one is the area with the highest slopes and elevations, consisting of low-permeability materials (in orange); (ii) unit two contains semi-permeable material (yellow) and has medium slopes; and (iii) unit three comprises permeable materials (light blue) and is characterized by having low slopes. The permeable unit has been verified due to the Manglaralto river channel, drilled wells, and plugs. These last structures help to retain the surface water of a river for its subsequent storage, infiltration, and recharge of the aquifer [41].

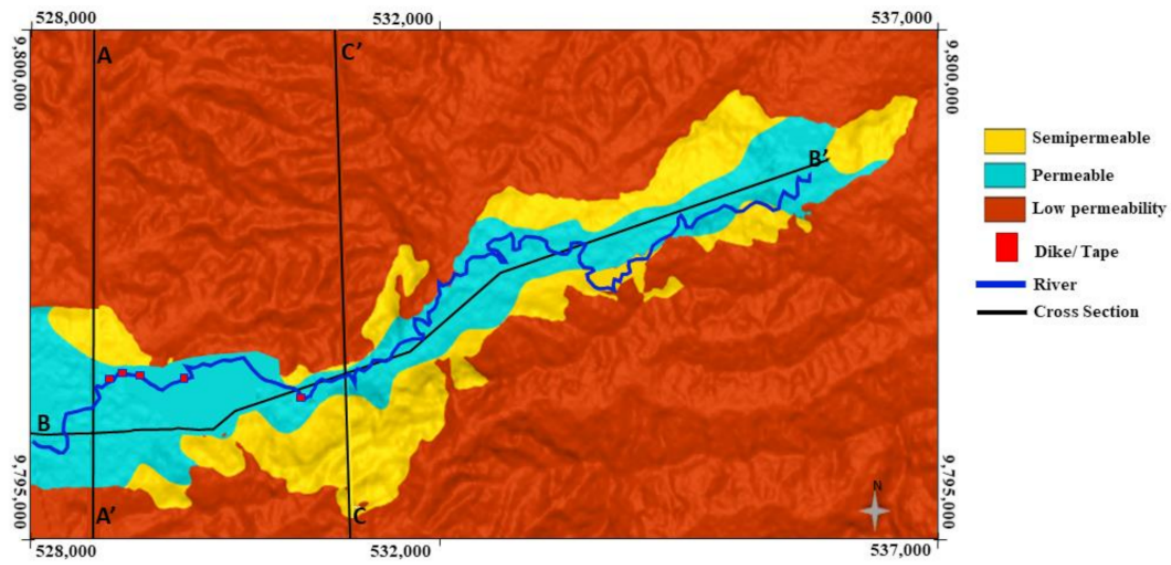

Figure 8. Plan view of the hydrogeological units modeled.

Besides this, three profiles have made, which are shown in Figure 9, to verify the above: (i) the A-A' cross-section shows the largest and most powerful area of the aquifer; (ii) the $\mathrm{B}-\mathrm{B}^{\prime}$ cross-section intersects the alluvial to show a profile of the geometry; finally, (iii) the $C-C^{\prime}$ cross-section has been made to observe the geometry of the preferential accumulation zones that are highlighted in the $\mathrm{B}^{-\mathrm{B}^{\prime}}$ cross-section. 
(a)

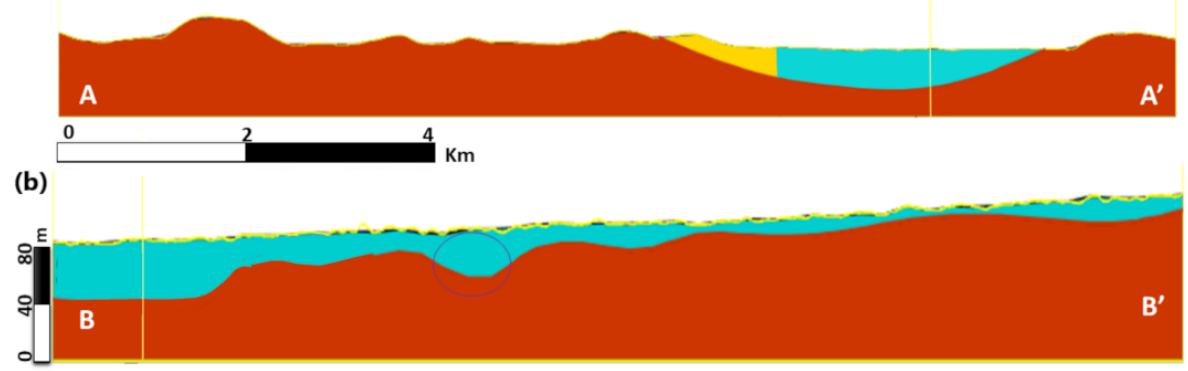

(c)

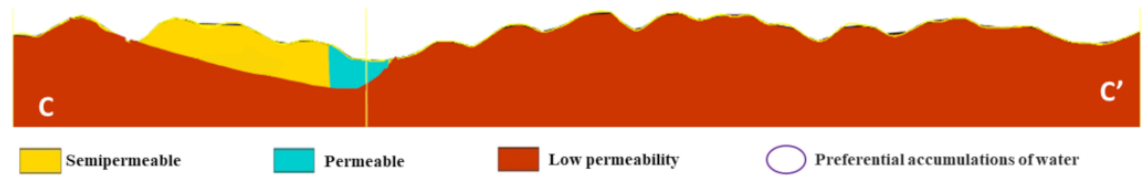

Figure 9. (a) $\mathrm{A}-\mathrm{A}^{\prime}$ cross-section of the lower part, in the broadest area of the alluvial. (b) B-B' cross-section along the permeable zone shows the water accumulations' geometry, highlighting the preferential accumulations. (c) $\mathrm{C}-\mathrm{C}^{\prime}$ cross-section of the geometry of the preferential accumulations of water.

\subsection{Geometric Model}

Unit one features low-permeability material. Unit two is silt and clays. Aquifer unit three (permeable unit) is gravel and sand; however, it also combines with clay material, as shown in Figure 10. Water is contained in the aquifer unit's pores; therefore, the gross volume $\left(2.03 \times 10^{8} \mathrm{~m}^{3}\right)$, shown in Table 4 is multiplied by the average porosity obtained from previous studies (0.22). As a result, a value of $45.3 \times 10^{6} \mathrm{~m}^{3}$ has been obtained. At this value, the data's piezometric level from 12 wells in the area must be considered, with a decrease of $30 \%$; the final result has been estimated at $13,596,000 \mathrm{~m}^{3}\left(13.6 \mathrm{Hm}^{3}\right)$. It is important to note that water cannot be drawn from the aquifer up to the maximum limit, due to the ecological balance.

\section{Geological Model}

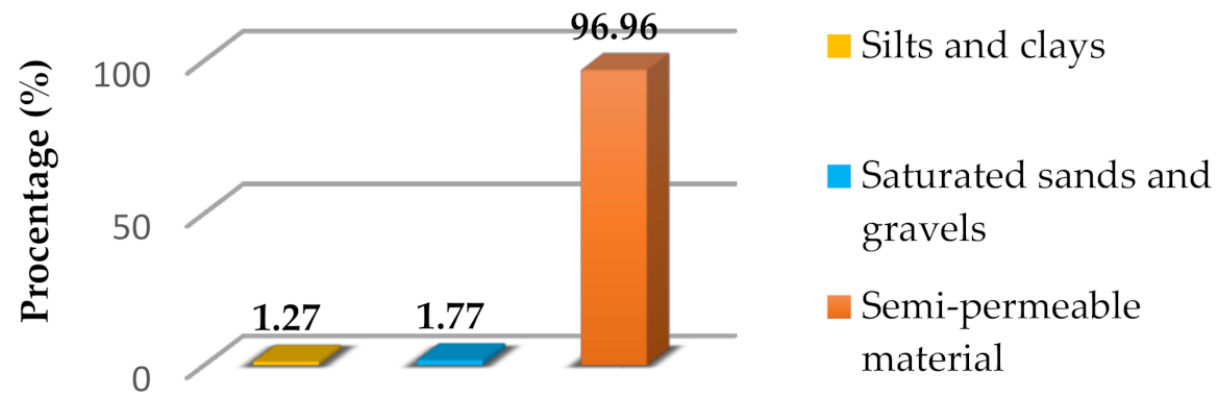

\section{Lithology}

Figure 10. Volume estimation with GeoModeller software.

Table 4. Results of volume estimation with GeoModeller software.

\begin{tabular}{ccc}
\hline Lithology & Volume $\left.\mathbf{( m}^{\mathbf{3}}\right)$ & Percentage (\%) \\
\hline Silts and clays & $1.45 \times 10^{8}$ & 1.27 \\
Saturated sands and gravels & $2.03 \times 10^{8}$ & 1.77 \\
Semi-permeable material & $1.11 \times 10^{10}$ & 96.96 \\
\hline
\end{tabular}


The three-dimensional model of the Manglaralto aquifer, generated with the 3D GeoModeller software, represents curves in the 2D and 3D viewers through a discretization or succession of rectilinear segments. This discretization is managed to create an excellent representation of its shape. Note that 3D GeoModeller represents surfaces and a triangulation assembly docked together. Therefore, the representation of these curves and surfaces depends on the number of segments and triangles used. Three parameters control this quality: first, 2D deflection, whose value is $0.001 \mathrm{~m}$; second, 3D deflection, with $0.0001 \mathrm{~m}$, and thirdly, a discretization of 1,000,000 m. Additionally, the model has an accuracy of $1 \mathrm{~m}$. All the parameters described demonstrate the sensitivity of the geometric model generated. Likewise, its reliability has been evidenced, once in 2020 and early 2021, as the Manglaralto sector is under the influence of the La Niña climate phenomenon. This has produced low rainfall, and therefore the recharge to the aquifer has been minimal in relation to the last five years. Despite this, the geometric model has contributed to the geographical recognition of accumulations of water in strategic places, where the base of the river has greater depth. This detail has been used for the construction of two water wells, which have helped in this emergency situation. Additionally, the geophysical information and the location of existing wells have served to provide robustness in the input information of the geometric model.

\subsection{Sustainable Use Proposals}

Based on the geometric model and the estimated volume, distinguishing factors that influence the aquifer have been identified. The factors are examined against four goals (relating to water resources) of the predefined guide to the SDGs to analyze the aquifer's sustainable use.

Table 5 presents a qualitative analysis of nine indicators of Agenda 2030 concerning the four ECSE factors of the Brundtland Commission [64,65]. The indicators are related to the following SDGs: 1. Putting an end to poverty (indicator 1.4.1); 6. Guaranteeing the availability and sustainable water and sanitation (indicators 6.1.1, 6.2.1, 6.3.2, 6.4.1, 6.4.2); 13. Climate action (indicators 13.1, 13.3); and 15. Protecting, restoring and promoting the sustainable use of ecosystems (indicator 15.1.2). The goals were selected based on the following criteria:

- Goal 1: The Manglaralto sector is a rural area of poverty in Ecuador. Moreover, there is no government responsibility for water supply.

- Goal 6: Year after year, JAAPMAN has increased accessibility to essential services such as drinking water and sewerage, to the attached communities; besides which, the central socio-economic axis of the parish is the river-aquifer system.

- Goal 13: Due to changes in weather patterns, rising sea levels, and extreme weather events (droughts/floods), it is necessary to evaluate the conditions of the Manglaralto coastal aquifer.

- Goal 15: Manglaralto, because it depends economically on groundwater, is obliged to protect its basin. Reforestation projects have been undertaken throughout the basin once a year. Thanks to the Ministry of the Environment, the basin's upper part (beginning) has been named a Reserve, which guarantees protected forests that help against climate change.

Figure 11 shows the schematic relationship between the four factors for sustainable development analyzed in this study, seeking to visualize the links between the factors and their indicators better. 
Table 5. Analysis matrix of indicators of the sustainable development goals (SDGs) of the Agenda 2030 for environmental, economic, cultural, and social factors.

\begin{tabular}{l} 
Factor \\
\hline $\begin{array}{l}\text { Change in the efficient use of water resources over } \\
\text { time. (6.4.1) }\end{array}$ \\
$\begin{array}{l}\text { The proportion of good-quality water bodies. } \\
(6.3 .2)\end{array}$ \\
Environmental \\
$\begin{array}{l}\text { The proportion of the population using health } \\
\text { services' } \\
\text { risk-free managed sanitation. (6.2.1) }\end{array}$ \\
\hline
\end{tabular}

Strengthened resilience and adaptive capacity to climate-related risks and natural disasters in all countries. (13.1)

Change in the efficient use of water resources over time.

The proportion of sites important to terrestrial and

Cultural freshwater biodiversity included in protected areas. (15.1.2)

Improved education, awareness, and human and institutional capacity regarding climate change mitigation, adaptation, reduction of its effects, and early warnings. (13.3)

The population proportion living in households with access to essential services.

(1.4.1)

Social

Change in the efficient use of water resources over time.

(6.4.1)

The proportion population using safe, managed drinking water services.

(6.1.1)

Economic

Level of water stress: freshwater withdrawal in proportion to available freshwater resources. (6.4.2)

\section{Indicator Status}

The geometric model provides an understanding of the aquifer's horizons and estimates to control the incidence in its use. It is a community project with its members' participation to control the quality of its waters [47].

All the JAAPMAN wells (12) are currently located on the south bank of the river at less than $100 \mathrm{~m}$ apart. The intense exploitation and the proximity to the coastline have caused the closure of two of them, resulting in only $83 \%$ (10 wells) having extracted good-quality water.

In two of the wells closest to the coastline, the extracted water presents high salinity due to marine intrusion caused by the coastal aquifer's overexploitation [43]. The construction of 'tapes' has helped to control this situation.

According to population projections for 2020,64\% of the population attached to JAAPMAN (Montañita, Manglaralto, and Libertador Bolívar) will use the sewerage and wastewater treatment service, with oxidation pools $[66,67]$.

Thanks to the joint work of JAAPMAN and the Escuela Superior Politécnica del Litoral (ESPOL) universities through CIPAT-ESPOL, the construction of dykes/'tapes' has been achieved, which have helped to recharge the coastal aquifer since 2015, thereby gaining some resilience $[41,48]$.

Through the construction of five 'tapes', shown in Figure 7, the commune's ancestral knowledge has rescued, since they involve a technical-artisan construction. These retain rainwater and benefit the aquifer recharge [41,49].

Natural areas cover $44.03 \%$ of the Manglaralto parish territory natural areas (18,673 has) [45]. This parish has protected areas such as the Chongón-Colonche protective forest, the Dos Mangas nature reserve, and the Loma Alta reserve [68]. These zones allow recharging and help balance the aquifer ecosystem [69].

Socialization about the water resource's sustainability and resilience is necessary to create a parish water culture, especially for the new generations [70].

Of the Manglaralto parish homes, $85.6 \%$ have electricity, and $92.7 \%$ have supplied water managed by the JAAPMAN (public network) [42,70].

For the year 2017, the water boards supplied 30.8\% of Ecuador's rural areas [71]. The control of the Manglaralto aquifer is given by JAAPMAN, which is a communal organization that involves the whole of society. Therefore, creating the geometric model allows them to approximate the aquifer horizons to improve management.

JAAPMAN complies with the norm of the Ecuadorian Institute of Standardization INEN 1108 (drinking water) and has water treatment for consumption [71]. It provides safe water to approximately $54.1 \%$ of the population of the Manglaralto parish (40,000 people including locals and tourists) [72,73].

An aquifer volume of $13.6 \mathrm{Hm}^{3}$ has been estimated, with annual water extraction of approximately $685,000 \mathrm{~m}^{3}$. An annual increase of $9 \%$ is obtained due to the native and floating population (tourism). There is a deficit in recharging in the sector due to it being a semi-arid climate zone, which projects future water stress if aquifer conservation measures have not taken. 


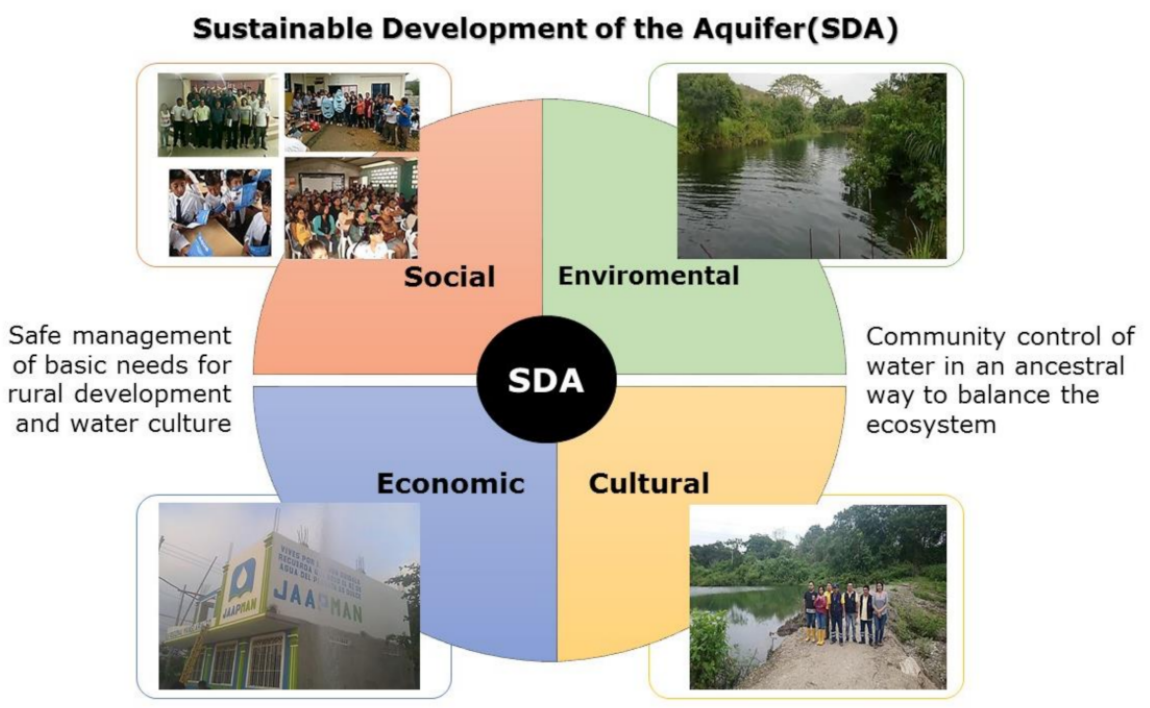

Figure 11. Relationship between environmental, economic, cultural, and social factors for the Sustainable Development of the Aquifer (DSA).

\section{Discussion}

The free porous coastal aquifer has been conditioned by the topography and geomorphology of the alluvial terrace. The riverbed follows the meanders in the alluvial terrace. The geometric model discerned that towards the mouth of the sea (west), the aquifer is more powerful, reaching up to $30 \mathrm{~m}$ of power, and that it is of lower power towards the high areas $(4 \mathrm{~m})$, as shown in Figure 12.

(a)

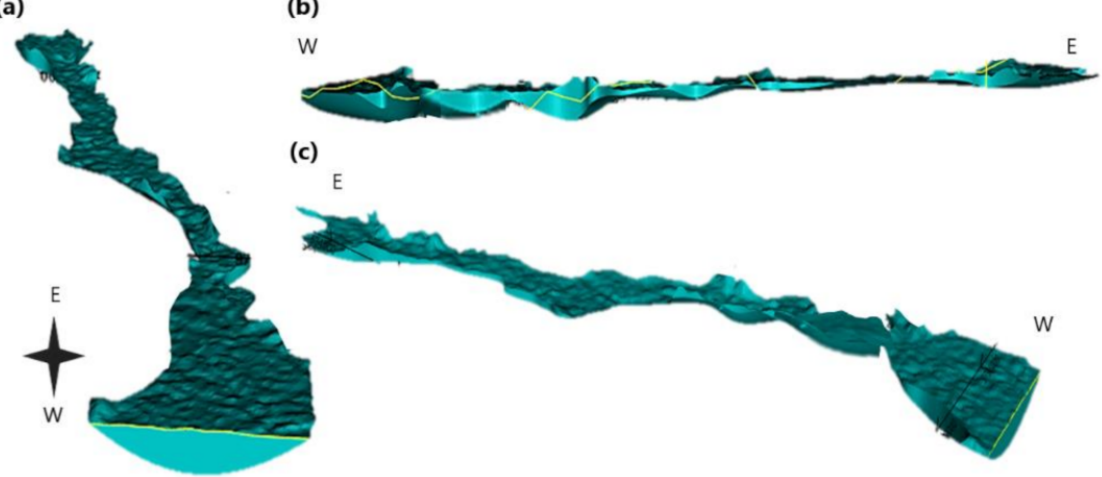

Figure 12. Different views of the aquifer geometric model. (a) Front west-east view direction. (b) South side view in a west-east direction; (c) north side view in an east-west direction.

The turbulence of the river in the upper zone transports the sediments deposited mainly towards the sea's mouth, in comparison with the VES correlation performed by Valencia [42], which indicates an average power of the water layer of $17 \mathrm{~m}$ to the west with a decrease of up to $3 \mathrm{~m}$ to the east. Studies show that there are apparent zones of preferential accumulation of sediments due to meanders. With this study, a more significant number of SEVs were used and a greater depth reached. The three-dimensional visualization detects the peculiarities of the terrain and the shapes of the alluvial terrace. There are strategic areas with greater depths in the terraces and, therefore, the aquifer, which has been protected for conservation, so the community has declared them a natural reserve to favor the aquifer's recharge.

The area of the basin associated with the Manglaralto River covers 5400 hectares. Using the GeoModeller software, an aquifer water volume has been estimated at $13.6 \mathrm{Hm}^{3}$. 
However, other authors, such as Valencia J., estimate the value at $9.9 \mathrm{Hm}^{3}$ [42], but it should have been noted that their study was carried out in the dry season, recovering from an intense drought in the area. Furthermore, Herrera G. [40] indicates an approximate value of $8.5 \mathrm{Hm}^{3}$ with a methodology similar to that of Valencia, simplifying the surface's calculation multiplied by the average depth. In comparison, the program's volume is a more accurate estimate because it considers the aquifer geometry's details. Another factor may be the use of 'tapes' in the river bed since this helps to recharge the aquifer, as has been done in other places, such as Spain [74] and Cuba [75]. In other places, the rescue of ancestral knowledge has been applied to accumulate rainwater in areas with scarcity $[76,77]$.

The methodology used in the GeoModeller software for geometric modeling is like that of studies carried out in aquifers in Colombia [57], Spain [58,59], and Australia [60]. They incorporate input data such as topography, geology, and geophysics in the software results in a three-dimensional model that allows us to understand the aquifer's geometry. For the present study, the model has contrasted with information from the wells drilled in the area and, in general, the model shows a good coupling with reality.

Modeling is the first step to analyze an aquifer from different factors, as in this case, which examines its impact on its sustainable use through an analysis matrix that we call ECSE, where the indicators of the SDG Agenda 2030 are linked to four factors created by the Brundtland Commission [62,63], for a compilation of critical sustainable development links concerning the aquifer. These essential links have been reorganized into a Venn diagram, which allows a synthetic and holistic vision for sustainable aquifer management, which is effected through community engagement and scientific advice from academia. It allows us to note that the factors are closely linked to each other, and that a comprehensive vision is required for sustainable water use over time. In comparison, other studies also indicate that water plays a role in the economy and the environment [78-80]. To ensure sustainable management, effective social participation and community ownership of the source care is necessary [81].

\section{Conclusions}

The three-dimensional model generated by the geophysical surveys correlated with topography and geology allow us to know the aquifer's geometry. The Manglaralto River transports the sediments that make up the aquifer. They have the properties of being porous and permeable, associated with gravel and sand, with intercalations of silts and clays. The volume of water in this layer was estimated by the GeoModeller software in 13.6 $\mathrm{Hm}^{3}$. The model estimates that the most significant thicknesses are those closest to the coast (west) with approximate thicknesses of up to $30 \mathrm{~m}$ and up to $4 \mathrm{~m}$ near the Dos Mangas sector (east). Besides this, there are places with preferential materials for accumulating water with an approximate thickness of up to $40 \mathrm{~m}$ due to meanders, which have served wells' locations and construction.

The ECSE analysis, based on the SDG Agenda 2030 indicators, shows that the aquifer has an essential impact on the hydrographic basin and its natural resources. The inhabitants and their culture have contributed some sustainability aspects to the area, such as the aquifer's recharge, through the rescue of ancestral knowledge applied to the river and aquifer management. Also, it reflects matters to attend to, since the aquifer presents a danger of contamination due to the intense water extraction. For this reason, the distribution of future wells should improve and more 'tapes' should be built to help artificially recharge the aquifer and allow an environmental balance. This social connection allows community water management to supply to rural communities safely. However, lately, they have to face a new influence regarding climate change; the La Niña phenomenon associated with a drought period brings new challenges.

The modeling had limitations, such as the amount of VES and the location of these. Since there is less information, this lack can create blind areas. It could be improved by locating the VES in a mesh. However, in this study, the terrain characteristics did not 
allow this type of spacing. Thus, the model has been generated using geoelectric profiles, contrasted with the information of water wells drilled in the area to ascertain whether the model had a good connection with reality. However, introducing a more significant amount of reliable information would generate higher quality model validation.

For this reason, it would also be essential to carry out studies of structural faults, and gain information on drilling cores and seismic profiles in the area. Notably, this study is a first approximation of the aquifer's shape and is the first of its kind, carried out in the Ecuadorian coast's semi-desert area. Still, its most significant importance lies in the fact that the rural population that inhabits the area establishes the aquifer management through social, cultural, economic, and environmental axes, whose synchronization occurs through the knowledge of what they have through studies of the geometric model.

Supplementary Materials: The following are available online at https:/ / www.mdpi.com/article/10 $.3390 / w 13070923 /$ s1, Figure S1: Map of the geology of the area, in which the location of the VES carried out is detailed.

Author Contributions: Conceptualization, G.H.-F. and P.C.-M.; methodology, G.H.-F., X.Q.-B., P.C.M., F.J.M., F.M.-C., and J.P.-Ú.; software, X.Q.-B.; validation, P.C.-M., F.M.-C., F.J.M., and X.Q.-B.; formal analysis, G.H.-F., P.C.-M., and F.M.-C.; investigation, G.H.-F., X.Q.-B., and P.C.-M.; writingoriginal draft preparation, X.Q.-B., P.C.-M., and F.M.-C.; writing-review and editing, G.H.-F., F.J.M., X.Q.-B., P.C.-M., F.M.-C., and J.P.-Ú.; supervision, G.H.-F., P.C.-M., and F.M.-C.; project administration, G.H.-F., P.C.-M., F.J.M., F.M.-C., and J.P.-Ú. All authors have read and agreed to the published version of the manuscript.

Funding: This research received no external funding.

Institutional Review Board Statement: Not applicable.

Informed Consent Statement: Not applicable.

Data Availability Statement: Not applicable.

Acknowledgments: This work has been possible thanks to the valuable collaboration of JAAPMAN, the ESPOL research project: "Registration of geological and mining heritage and its impact on the defense and preservation of geodiversity in Ecuador", to the Social Linkage Project "Integration of the management of water in hydrographic basins of the parish of Manglaralto", and the research projects UPSE “Project Geopark Peninsula Santa Elena" and "Geophysical and Hydrochemical Characterization of the Manglaralto Aquifer for the Sustainability of the Water Resource". To Josué Briones, a researcher at CIPAT-ESPOL, for his collaboration. To Intrepid Geophysics for helping us give us a trial time in the GeoModeller Software to develop this research.

Conflicts of Interest: The authors declare no conflict of interest.

\section{References}

1. Ge, L.; Anten, N.P.R.; van Dixhoorn, I.D.E.; Feindt, P.H.; Kramer, K.; Leemans, R.; Meuwissen, M.P.M.; Spoolder, H.; Sukkel, W. Why we need resilience thinking to meet societal challenges in bio-based production systems. Curr. Opin. Environ. Sustain. 2016, 23, 17-27. [CrossRef]

2. Vannevel, R.; Goethals, P.L. Identifying Ecosystem Key Factors to Support Sustainable Water Management. Sustainability 2020, 12, 1148. [CrossRef]

3. Jounaid, H.; Attou, T.; Remmal, T.; Bouaziz, A. Securing Access to Drinking Water in North-Eastern Morocco: The Example of the Taourirt-Oujda Corridor. Water 2020, 12, 928. [CrossRef]

4. UNDAES (United Nations Department of Economic and Social Affairs). World Population Prospects: The 2017 Review, Key Findings and Advance Tables; Working Paper No. ESA/P/WP/248; UNDAES: New York, NY, USA, 2017.

5. UNGWAP (UNESCO Global Water Assessment Programme). United Nations World Report on Water Development 2019: Leave No One Behind; UNESCO: Paris, France, 2019.

6. Ceola, S.; Montanari, A.; Krueger, T.; Dyer, F.; Kreibich, H.; Westerberg, I.; Carr, G.; Cudennec, C.; Elshorbagy, A.; Savenije, H.; et al. Adaptation of water resources systems to changing society and environment: A statement by the International Association of Hydrological Sciences. Hydrol. Sci. J. 2016, 61, 2803-2817. [CrossRef]

7. Intergovernmental Panel on Climate Change. Climate Change 2014: Impacts, Adaptation and Vulnerability. Working Group II Contribution to the IPCC Fifth Assessment Report. Available online: http:/ / www.ipcc.ch/report/ar5/wg2 (accessed on 3 May 2020). 
8. Rodriguez-Sanchez, C.; Sarabia-Sanchez, F.J. Does Water Context Matter in Water Conservation Decision Behaviour? Sustainability 2020, 12, 3026. [CrossRef]

9. WHO (World Health Organization). Guides for the Quality of Water for Human Consumption, 4th ed.; WHO Graphics: Geneva, Switzerland, 2017.

10. Burek, P.; Satoh, Y.; Fischer, G.; Kahil, M.T.; Scherzer, A.; Tramberend, S.; Nava, L.F.; Wada, Y.; Eisner, S.; Flörke, M.; et al. Water Futures and Solution-Fast Track Initiative (Final Report); IIASA Working Paper: Laxenburg, Austria, 2016.

11. Setegn, S.; Melesse, A.; Haiduk, A.; Webber, D.; Wang, X.; McClain, M. Modeling hydrological variability of fresh water resources in the Rio Cobre watershed, Jamaica. Catena 2014, 120, 81-90. [CrossRef]

12. Duran-Llacer, I.; Munizaga, J.; Arumí, J.L.; Ruybal, C.; Aguayo, M.; Sáez-Carrillo, K.; Arriagada, L.; Rojas, O. Lessons to Be Learned: Groundwater Depletion in Chile's Ligua and Petorca Watersheds through an Interdisciplinary Approach. Water 2020, 12, 2446. [CrossRef]

13. Chatton, E.; Aquilina, I.; Pételet-Giraud, E.; Cary, I.; Bertrand, G.; Labasque, T.; Hirata, R.; Martins, V.; Montenegro, S.; Vergnaud, V.; et al. Glacial recharge, salinisation and anthropogenic contamination in the coastal aquifers of Recife (Brazil). Sci. Total Environ. 2016, 569-570, 1114-1125. [CrossRef]

14. Famiglietti, J. The global groundwater crisis. Nat. Clim. Chang. 2014, 4, 945-948. [CrossRef]

15. Lezzaik, K.; Milewski, A.; Mullen, J. The groundwater risk index: Development and application in the Middle East and North Africa region. Sci. Total Environ. 2018, 628-629, 1149-1164. [CrossRef]

16. Ferguson, G.; Gleeson, T. Vulnerability of coastal aquifers to groundwater use and climate change. Nat. Clim. Chang. 2012, 2, 342-345. [CrossRef]

17. Werner, A.D.; Bakker, M.; Post, V.E.A.; van den Bohede, A.; Lu, C.; Ataie-Ashtiani, B.; Simmons, C.T.; Barry, D.A. Seawater intrusion processes, investigation and management: Recent advances and future challenges. Adv. Water Resour. 2013, 5, 3-26. [CrossRef]

18. Seyam, M.; Alagha, J.S.; Abunama, T.; Mogheir, Y.; Affam, A.C.; Heydari, M.; Ramlawi, K. Investigation of the Influence of Excess Pumping on Groundwater Salinity in the Gaza Coastal Aquifer (Palestine) Using Three Predicted Future Scenarios. Water 2020, 12, 2218. [CrossRef]

19. Correa, G. Access to water, poverty, and development in Colombia. J. Univ. Salle 2017, 72, 27-46.

20. Amer, R.; Ripperdan, R.; Wang, T.; Encarnación, J. Groundwater quality and management in arid and semi-arid regions: Case study, Central Eastern Desert of Egypt. J. Afr. Earth Sci. 2012, 69, 13-25. [CrossRef]

21. Allow, A.K. The use of injection wells and a subsurface barrier in the prevention of seawater intrusion: A modelling approach. Arab. J. Geosci. 2012, 5, 1151-1161. [CrossRef]

22. Dashora, Y.; Dillon, P.; Maheshwari, B.; Soni, P.; Dashora, R.; Davande, S.; Purohit, R.C.; Mittal, H.K. A simple method using measurements applied to estimate dam recharge in Rajasthan, India. Sustain. Water Resour. Manag. 2017, 4, 301-316. [CrossRef]

23. Maheshwari, B.; Varua, M.; Ward, J.; Packham, R.; Chinnasamy, P.; Dashora, Y.; Dave, S.; Soni, P.; Dillon, P.; Purohit, R.; et al. The Role of Transdisciplinary Approach and Community Participation in Village Scale Groundwater Management: Insights from Gujarat and Rajasthan, India. Water 2014, 6, 3386-3408. [CrossRef]

24. Gale, M.I. Techniques for management of aquifer recharge in arid and semi-arid regions. In Proceedings of the Regional Workshop on Management of Aquifer Recharge and Water Harvesting in Arid and Semi-arid Regions of Asia, Yazd, Iran, 27 November 2005.

25. Brundtland, G. Our Common Future-Call for Action. Environ. Consevr. 1987, 14, 291-294. [CrossRef]

26. United Nations (UN). The 2030 Agenda and the Sustainable Development Goals: An opportunity for Latin America and the Caribbean. Goals, Targets and Global Indicators; Economic Commission for Latin American and the Caribbean (ECLAC): Santiago, Chile, 2018.

27. Thornton, J.; Mariethoz, G.; Brunner, P. A 3D geological model of a structurally complex Alpine region as a basis for interdisciplinary research. Sci. Data 2018, 5, 180238. [CrossRef]

28. Calcagno, P.; Courrioux, G.; Guillen, A.; Fitzgerald, D.; McInerney, P. How 3D implicit geometric modeling helps to understand geology: The 3D GeoModeller Methodology. In XI International Congress, Society for Mathematical Geology; Université de Liège: Liège, Belgium, 2006.

29. Calcagno, P.; Chilés, J.; Corrioux, G.; Guillen, A. Geological modelling from field data and geological knowledge, Part IModelling method coupling 3D potential-field interpolation and geological rules. Phys. Earth Planet. Inter. 2008, 171, $147-157$. [CrossRef]

30. Maxelon, M.; Renard, P.; Courrioux, G.; Brändli, M.; Mancktelow, N. A workflow to facilitate three-dimensional geometrical modelling of complex poly-deformed geological units. Comput. Geosci. 2009, 35, 644-658. [CrossRef]

31. Moya, C.; Raiber, M.; Cox, M. Three-dimensional geological modelling of the Galilee and central Eromanga basins, Australia: New insights into aquifer/aquitard geometry and potential influence of faults on inter-connectivity. J. Hydrol. Reg. Stud. 2014, 2, 119-139. [CrossRef]

32. Hassen, I.; Gibson, H.; Hamzaoui-Azaza, F.; Negro, F.; Rachid, K.; Bouhlila, R. 3D geological modeling of the Kasserine Aquifer System, Central Tunisia: New insights into aquifer-geometry and interconnections for a better assessment of groundwater resources. J. Hydrol. 2016, 539, 223-236. [CrossRef] 
33. Di Salvo, C.; Di Luzio, E.; Mancini, M.; Moscatelli, M.; Capelli, G.; Cavinato, G.P.; Mazza, R. GIS-based hydrostratigraphic modeling of the city of Rome (Italy): Analysis of the geometric relationships between a buried aquifer in the Tiber Valley and the confining hydrostratigraphic complexes. Hydrogeol. J. 2012, 20, 1549-1567. [CrossRef]

34. Sakiyan, J.; Yazicigil, H. Sustainable development and management of an aquifer system in western Turkey. Hydrogeol. J. 2004, 12, 66-80. [CrossRef]

35. Bingxian, L.; Liangchen, Z.; Guonian, L.; A-Xing, Z. 3D geological modelling based on 2D geological map. Ann. GIS 2018, 23, 117-129. [CrossRef]

36. Massuel, S.; George, B.; Gaur, A.; Nune, R. Groundwater modeling for sustainable resource management in the Musi Catchment, India. In Proceedings of the International Congress on Modelling and Simulation, Christchurch, New Zealand, 10-13 December 2007.

37. Nasrin, S.; Zhu, X.; Cartwright, I.; Ailleres, L. Visualization of aquifers for sustainable water management. Environ. Qual. Manag. 2010, 21, 253-274. [CrossRef]

38. IAEA (International Atomic Energy Agency). Estudios de Hidrología Isotópica en América Latina 2006; Organismo Internacional de Energía Atómica: Vienna, Austria, 2009.

39. Galárraga-Sánchez, R.; Taco Cañizares, L. Modelado de un acuífero regional andino para determinar sus características y vulnerabilidad: El caso del acuífero del río Cutuchi, Ecuador. In Manejo Integrado de Aguas Subterráneas, 1st ed.; Reynolds, J., Ed.; Universidad Estatal a Distancia (EUNED): San José, Costa Rica, 2002; Volume 1, pp. 189-202.

40. Herrera, G. Estudio para un Modelo de Gestión de un Acuífero Costero, Mediante Metodologías Participativas y Análisis Geoestadístico en el Marco del Desarrollo Local. Manglaralto, Ecuador. Ph.D. Thesis, Universidad Politécnica de Madrid, Madrid, Spain, 2015.

41. Carrión, P.; Herrera, G.; Briones, J.; Sánchez, C.; Limón, J. Practical adaptations of ancestral knowledge for groundwater artificial recharge management of Manglaralto coastal aquifer, Ecuador. WIT Trans. Ecol. Environ. 2018, 217, 375-386. [CrossRef]

42. Valencia, J. Análisis Hidrogeológico de la Cuenca del río Manglaralto Para la Caracterización de Sus Sistemas Acuíferos. Bachelor's Thesis, ESPOL Polytechnic University, Guayaquil, Ecuador, 2017.

43. Saeteros, M. Estimación de la Tarifa del Agua de Los Acuíferos Costeros Para la Gestión Sostenible del Recurso. Caso de Estudio: Manglaralto, Santa Elena, Ecuador. Bachelor's Thesis, ESPOL Polytechnic University, Guayaquil, Ecuador, 2014.

44. Morante, F.; Montalván, J.F.; Carrión, P.; Herrera, G.; Heredia, J.; Elorza, F.J.; Pilco, D.; Solórzano, J. Hydrochemical and geological correlation to establish the salinity of groundwater of the coastal aquifer of the Manglaralto-Ecuador river basin. WIT Trans. Ecol. Environ. 2019, 229, 139-149. [CrossRef]

45. Instituto Nacional de Estadísticas y Censo. Reporte de Pobreza por Consumo: Ecuador 2006-2014; Banco Mundial: Quito, Ecuador, 2015.

46. Secretaría de Planificación Estratégica del Ecuador (SENPLADES). Plan de Desarrollo y Ordenamiento Territorial-Cantón Santa Elena 2014-2019; Gobierno Autónomo de Santa Elena: Santa Elena, Ecuador, 2015.

47. Herrera, G.; Carrión, P.; Briones, J. Prácticas de gestión para una comunidad sostenible y su incidenciaen el desarrollo, ManglaraltoSanta Elena, Ecuador. In Proceedings of the 17th LACCEI International Multi-Conference for Engineering, Education, and Technology: "Industry, Innovation, and Infrastructure for Sustainable Cities and Communities", Montego Bay, Jamaica, 21-26 July 2019.

48. Herrera-Franco, G.; Carrión-Mero, P.; Aguilar-Aguilar, M.; Morante-Carballo, F.; Jaya-Montalvo, M.; Morillo-Balsera, M. Groundwater Resilience Assessment in a Communal Coastal Aquifer System. The Case of Manglaralto in Santa Elena, Ecuador. Sustainability 2020, 12, 8290. [CrossRef]

49. Gricelda, H.F.; Paúl, C.M.; Niurka, A.M. Participatory Process for Local Development: Sustainability of Water Resources in Rural Communities: Case Manglaralto-Santa Elena, Ecuador. In Handbook of Sustainability Science and Research; Springer: Cham, Switzerland, 2018; pp. 663-676.

50. Herrera, G.; Carrión, P.; Briones, J. Geotourism potential in the context of the geopark project for the development of Santa Elena Province, Ecuador. WIT Trans. Ecol. Environ. 2018, 217, 557-568.

51. Herrera-Franco, G.; Montalván-Burbano, N.; Carrión-Mero, P.; Apolo-Masache, B.; Jaya-Montalvo, M. Research Trends in Geotourism: A Bibliometric Analysis Using the Scopus Database. Geosciences 2020, 10, 379. [CrossRef]

52. Mata-Perelló, J.; Carrión, P.; Molina, J.; Villas-Boas, R. Geomining Heritage as a tool to promote the social development of rural communities. Geoheritage 2018, 167-177. [CrossRef]

53. Herrera-Franco, G.; Carrión-Mero, P.; Alvarado, N.; Morante-Carballo, F.; Maldonado, A.; Caldevilla, P.; Briones-Bitar, J.; Berrezueta, E. Geosites and Georesources to Foster Geotourism in Communities: Case Study of the Santa Elena Peninsula Geopark Project in Ecuador. Sustainability 2020, 12, 4484. [CrossRef]

54. Álvarez-García, J.; Durán-Sánchez, A.; Del Río-Rama, M.D.C. Scientific Coverage in Community-Based Tourism: Sustainable Tourism and Strategy for Social Development. Sustainability 2018, 10, 1158. [CrossRef]

55. Gleeson, T.; Wada, Y.; Bierkens, M.; Van Beek, L. Water balance of global aquifers revealed by groundwater footprint. Nature 2012, 488, 197-200. [CrossRef] [PubMed]

56. Richey, A.; Thomas, B.; Lo, M.; Famiglietti, J.; Swenson, S.; Rodell, M. Uncertainty in global estimates of groundwater storage in a framework of total groundwater stress. Water Resour. Res. 2015, 51, 5198-5216. [CrossRef] [PubMed] 
57. Rodriguez-Estrella, T. The problems of overexploitation of aquifers in semi-arid areas: The Murcia Region and the Segura Basin (South-east Spain) case. Hydrol. Earth Syst. Sci. Discuss. 2012, 9, 5729-5756. [CrossRef]

58. Burbano, N.; Becerra, S.; Pasquel, E. Introduction to the Hydrogeology of Ecuador, 2nd ed.; INAHMI: Quito, Ecuador, 2015.

59. Bacca, J.; Hernández, O.; Vasquez, L. Determinación de la geometría del acuífero de Morrosquillo y geología detallada del acuífero de Toluviejo, Sucre. Geol. Colomb. 2010, 35, 87-101. [CrossRef]

60. Rey, C.; García, J.; Marín, C.; Reguera, M.; Jiménez, A. Desarrollos Metodológicos en Geología del Subsuelo Para la Caracterización de Recursos Hidrogeológicos Profundos de la Provincia de Alicante (HIDROPROAL); Instituto de Geológico y Minero de España (IGME): Alicante, Spain, 2013.

61. Marín Lechado, C.; González, A.; Ruiz, A.; Cifuentes, V. El Modelo Geológico 3D del Acuífero de la Loma de Úbeda; SIAGA: Huelva, Spain, 2018.

62. Gill, B.; Cherry, D.; Adelana, M.; Cheng, X.; Reid, M. Using three-dimensional geological mapping methods to inform sustainable groundwater development in a volcanic landscape, Victoria, Australia. Hydrogeol. J. 2011, 19, 1349-1365. [CrossRef]

63. Vance, T.C.; Merati, N.; Mesick, S.M.; Moore, C.W.; Wright, D.J. GeoModeller. In Proceedings of the 15th annual ACM international symposium on Advances in geographic information systems-GIS '07; ACM Press: New York, NY, USA, 2007; p. 1.

64. UNESCO. Report of the World Commission on the Environment and Development (Brundtland Commission): Our Common Future; United Nations (UN): Washington, DC, USA, 2001.

65. Statistical Commission on the 2030. Agenda for Sustainable Development. Framework of Global Indicators for the Sustainable Development Goals and 2030 Agenda Targets for Sustainable Development; UNSD: New York, NY, USA, 2017.

66. Fascículo Provincial de Santa Elena. Available online: https://www.ecuadorencifras.gob.ec/wp-content/descargas/Manulateral/Resultados-provinciales/santa_elena.pdf (accessed on 20 April 2020).

67. Santa María Suárez, G.; Molina Benavides, L.; Clery Aguirre, A.; Mera Cedeño, M. Mapa Estratégico de las Necesidades de la Provincia de Santa Elena, 1st ed.; Universidad Estatal Península de Santa Elena (UPSE): La Libertad, Ecuador, 2016.

68. Junta de Agua Regional Valdivia; Corporación La Noble Guadua; Asociación del Manglar De Palmar; Junta de Agua Regional Olón and Fundación Brethren y Unida. Sistematización de la Asociación Para la Intervención en el Biocorredor Chongón Colonche en Busca de Buenvivir; Gobierno Autónomo Descentralizado de Santa Elena: Santa Elena, Ecuador, 2015.

69. Ayerza, A. Water importance of the forests of the Chongón- Colonche mountain range for the arid lands of northwest Santa Elena. Zero Latitude Forests 2019, IX, 16-30.

70. Herrera, G.; Carrión, P.; Yambay, K.; Briones, J. Educational considerations for conservation management and sustainable development of a watershed. Manglaralto, Santa Elena-Ecuador. In Proceedings of the INTED2019 Proceedings; IATED: Valencia, Spain, 2019; Volume 1, pp. 9243-9250.

71. Gestión de Agua Potable y Alcantarillado. Available online: https://www.ecuadorencifras.gob.ec/documentos/web-inec/ Encuestas_Ambientales/Municipios_2017/Agua_potable_alcantarillado-2017/Boletin\%20tecnico\%20APA\%202017.pdf (accessed on 20 April 2020).

72. Acosta, M.; Basani, M.; Solís, H. Practices and Knowledge in Community Water Management for Human Consumption; Inter-American Development Bank: Washington, DC, USA, 2019.

73. Aiello, A.E.; Coulborn, R.M.; Perez, V.; Larson, E.L. Effect of hand hygiene on infectious disease risk in the community setting: A meta-analysis. Am. J. Public Health 2008, 98, 1372-1381. [CrossRef]

74. Rodríguez-Estrella, T.; Martínenz, M.; Romero, A. Use of existing hydrological correction levees for refilling aquifers and proposed new ones in the Quipar River basin (Southeast of Spain). Ser. Hydrogeol. Undergr. Waters 2006, 17, 413-418.

75. Cabrera-Estupiñán, E.; Hernández-Valdés, A. Regional groundwater modeling with a local mesh refinement. Algorithm presentation and validation. Tecnol. Cienc. Agua 2011, 2, 65-82.

76. Van Meter, K.J.; Basu, N.B.; Tate, E.; Wyckof, J. Monsoon Harvests: The Living Legacies of Rainwater Harvesting. Environ. Sci. Technol. 2014, 48, 4217-4225. [CrossRef] [PubMed]

77. Berndtsson, R.; Jebari, S.; Hashemi, H.; Wessels, J. Traditional water management techniques: Do they have a role in post arab spring middle east? In Hydrological Sciences Journal; Taylor \& Francis: Abingdon, UK, 2014.

78. Banihabib, M.; Hashemi, F.; Shabestari, M. A Framework for Sustainable Strategic Planning of Water Demand and Supply in Arid Regions. Sustain. Dev. 2017, 25, 254-266. [CrossRef]

79. Ghafoori Kharanagh, S.; Banihabib, M.; Javadi, S. An MCDM-based social network analysis of water governance to determine actors' power in water-food-energy nexus. J. Hydrol. 2020, 581, 124382. [CrossRef]

80. Durán-Sánchez, A.; Álvarez-García, J.; Del Río-Rama, M.D.C. Sustainable Water Resources Management: A Bibliometric Overview. Water 2018, 10, 1191. [CrossRef]

81. Gleitsmann, B.; Kroma, M.; Steenhuis, T. Analysis of a rural water supply project in three communities in Mali: Participation and sustainability. Nat. Resour. Forum 2007, 31, 143-150. [CrossRef] 